\title{
The Control of Heat Radiation and Noise Performed by One of the Ship Production Companies in Indonesia
}

\section{Upaya Pengendalian Radiasi Panas Dan Kebisingan yang Dilakukan Oleh Salah Satu Perusahaan Produksi Kapal di Indonesia}

\author{
Tri Meidya Rahmawati ${ }^{1}$, Nidia Nuraini ${ }^{2}$ \\ ${ }^{1}$ Department of Environmental Health, Faculty of Public Health, Universitas Airlangga \\ Campus C Mulyorejo, Surabaya, East Java, 60115 Indonesia \\ ${ }^{2}$ Majoring in Environmental Health Poltekkes Surabaya \\ Jl. Pucang Jajar Tengah No.56 Surabaya, East Java, 60282 Indonesia
}

\begin{abstract}
Introduction: Noise is unwanted sound which comes from various working tools that can cause hearing loss on workers expressed in decibels $(\mathrm{dB})$. The ambient noise value in the workplace is $85 \mathrm{dBA}$. Ambient temperature in the workplace that is too hot is dangerous for the health of individual workers because it can result in various mental and physical health disorders. Methods: This research was conducted at one of the Ship Production Companies in Indonesia in March to June 2018. This type of research was descriptive and the design of this study was cross-sectional. The variables of this research were technical control, administrative control, and PPE control. The purpose of this study was to describe the efforts of controlling one of the Ship Production Companies in Indonesia in controlling heat stress and noise. The data used were primary data and secondary data. Result: One of the Ship Production Companies in Indonesia still had high heat and noise pressure. Three control efforts have been made including administrative control, technical control, and the use of PPE. The results shown in terms of technical control still did not meet the requirements because not all technical efforts were made. Meanwhile, administrative control and PPE control have met the requirements. Conclusion: Among the three control efforts that have not met the requirements yet are technical licensing while those that have met the requirements are administrative control requirements and the use of PPE.
\end{abstract}

Keywords: heat radiation, noise, ship production

\section{ABSTRAK}

Pendahuluan: Kebisingan adalah semua suara yang tidak diinginkan dan berasal dari berbagai macam alat-alat kerja yang dapat mengakibatkan gangguan pendengaran pekerja yang dinyatakan dalam satuan dsibel (dB). Nilai ambanag batas kebisingan ditempat kerja sebesar 85 dBA. Suhu lingkungan ditempat kerja yang terlalu panas berbahaya bagi kesehatan individu pekerja karena dapat mengakibatkan munculnya berbagai gangguan kesehatan mental maupun fisik. Metode: Penelitian ini dilakukan di salah satu Perusahaan Produksi Kapal di Indonesia pada bulan Maret sampai Juni 2018. Jenis Penelitian ini adalah deskriptif dan desain penelitian ini adalah cross sectional. Tujuan penelitian ini adalah untuk mendeskripsikan upaya pengendalian salah satu Perusahaan Produksi Kapal Di Indonesia dalam pengendalian tekanan panas dan kebisingan Variabel penelitian ini adalah pengendalian secara teknis, pengendalian secara administrarif, dan pengendalian APD. Data yang digunakan adalah data primer dan data sekunder. Hasil: Salah satu Perusahaan Produksi Kapal di Indonesia masih memiliki tekanan panas dan kebisingan yang cukup tinggi. tiga upaya pengendalian telah dilakukan antara lain pengendalian administratif, pengendalian teknik, dan penggunaan APD. Hasil yang ditunjukkan pengendalian secara teknik masih belum memenuhi syarat karena tidak semua upaya secara teknis dilakukan. Sedangkan pengendalain secara administrative dan pengendalian APD teleh memenuhi syarat. Simpulan: Dari tiga upaya pengendalian yang belum memenuhi syarat adalah pengandlian teknik sedangkan yang sudah memenuhi syarat pengendalian administratif dan pengandlian penggunaan APD dengan standard di tahun 2016 terbukti mampu menurunkan angka kecelakaan kerja di perusahaan tambang batu bara.

Kata kunci: kebisingan, produksi kapal, radiasi panas

Corresponding Author:

Tri Meidya Rahmawati

Email: tri.meidya.rahmawati-2018@fkm.unair.ac.id

Telephone: +6282234740497

(C2020 IJOSH All right reserved. Open access under CC BY NC-SA license doi: 10.20473/ijosh.v9i3.2020.289-296 Received April 15, 2020, received in revised form July 07, 2020, Accepted October 31, 2020, Published: November 2020 


\section{INTRODUCTION}

Workplace is every room or field, whether open, closed, movable or permanent where the laborers work, or those are often entered into labor for the purposes of a business and has sources of danger (Law, 1970). Occupational health is an activity carried out to improve the quality of life of workers through health promotion and prevention of Occupational Diseases including health checks, treatment and nutritious feeding and drinking. Factors that can worsen the work activities of workers can be eliminated by the policies of the leadership of the company. Uncomfortable working conditions can result from hot work environment activities that are out of balance with expended body heat. The influence of noise is related to various psychological and emotional factors. The effects that can occur from the noise that exceeds the threshold are loss of hearing function and physiological effects, while the psychological effects can include: emotional disturbances, sleep and rest disorders and communication disorders (Fahri, 2010).

Noise is all unwanted sound which comes from various working tools that can cause hearing loss workers expressed in decibels (dB). The Threshold Value that is still allowed to be accepted by workers at work and does not cause illness or health problems in daily work is $85 \mathrm{~dB}$ with a time of no more than 8 hours a day or 40 hours a week (Ministerial Regulation of Manpower and Transmigration, 2011). Other potential risk factors that can arise due to noise exposure in the workplace environment are stress disturbances, acceleration of the pulse, increased blood pressure, emotional stability, communication disorders and decreased work motivation. Noise can affect the comfort and health of workers who work in the factory environment. Disturbance that is not prevented or overcome can cause accidents, both to workers and those around them (Rimantho and Cahyadi, 2015). There are several factors that can affect the relationship between noise and the presence of a worker's health disorder. These factors can be in the forms of any intensity of noise, frequency of noise, and the length of time a person is exposed to the noise or noise (Adriyani, 2017).

Another dangerous source that can be found at work is physical conditions in the form of a hot work climate. This condition is easily found in industries in Indonesia, such as in the iron and steel, stone and ceramic metal industries, construction, manufacturing of rubber-based products, mining, glass and glass, textiles, etc. It is just that until now there has not been a maximum effort to overcome the source of the danger (Rahadian, 2018). Ambient temperature in the workplace that is too hot is dangerous for the workers' health because it can result in various complaints such as reduced comfort, impaired physical or mental appearance, causing fatigue, drowsiness, reduced work performance, emergence of serious health problems and increasing the possibility of work errors (Failasufa, Pawenang and Indarjo, 2014). Workplace heat as a physical stress can result in physiological changes in the body. Continuous heat exposure will result in heat strain, which is a series of physical responses arising from heat stress, including the amount of sweat produced, the amount of sweat that evaporates, changes in pulse and body temperature (Rahadian, 2018).

According to data from Jamsostek in Indonesia, there were 103,283 cases of work accidents recorded, in which there were 9 workers who participated in Social Security died daily due to work accidents. This number increased from year to year. On the comparison, the number of work accidents were 103,074 cases in 2012, 99,491 cases in 2011, and 98,711 cases in 2010 (Aryantiningsih and Husmaryuli, 2016). Meanwhile, according to the International Labor Organization (ILO) in their research concluded that in worldwide, there were more than 337 million work accidents and 2.3 million deaths per year, that means there are 6,300 people died per day due to work accidents or workrelated diseases (Fatimah and Indrawati, 2018).

Noise control can be done by several methods. The purpose of noise control is to ensure that workers avoid the effect of noise caused. There are six methods of controlling noise hazards according to the hazard control hierarchy those are elimination, substitution, isolation, engineering, administrative and personal protective equipment (Amalia, Jayanti and Kurniawan, 2015).

Ship Production Company in Indonesia is a company engaged in the manufacture of transportation, especially shipbuilding. Its main activities are producing types of ship transportation, providing repair and maintenance services for ship transportation, and general engineering with certain specifications based on orders. Various types of ship transportation have been produced by Ship Production Companies and have high quality products. The Ship Production Company in Indonesia also collaborates with the International 
Ship Production Company and is also supported by skilled human resources and complete facilities and infrastructure. However, there are various risks of work accidents that can occur in the Ship Production Company in Indonesia, one of them is due to environmental factors and work tools.

Environmental factors and working tools in Ship Production Company in Indonesia are sufficient to cause work accidents, because there are heat sources in the work environment (such as welding, hot surfaces, machinery) and sources of noise in the work environment (such as from operating equipment work, modeling, machinery). Ship Production Company in Indonesia processes for \pm 8 hours a day and apply overtime every 1 week. During the overtime hours, the company provides additional food intake in the form of snacks for workers and also implemented regular health checks at least once a year. The company also provides drinking water in the form of refill water according to the needs of workers, and before carrying out work activities, the company provides safety talk/ information about $\mathrm{K} 3$ to workers.

The purpose of this study was to investigate efforts to control heat radiation and noise in Ship Production Company in Indonesia which included technical protection services, administrative efforts, and PPE provision.

\section{METHODS}

This research method used descriptive research method. The purpose of this research was to make a description, picture, or painting in a systematic, factual and accurate manner about the facts, characteristics and relationships between the phenomena under investigation. Meanwhile the design used was cross-sectional because it was done at a certain time

The study was conducted at a Ship Production Company in Indonesia which was conducted for 4 months starting from March to June 2018. The total population in this study were 50 workers consisting of an accommodation section of 20 workers, 15 Tank Deck Workers, and 15 Whole Deck Workers. Meanwhile, the samples in this study were 44 workers. The research variables used included technical control, administrative control, and Personal Protective Equipment (PPE) control. Source of data obtained from this study consisted of primary data that includes observation, while the secondary data were obtained from the company.
Observations were made on field on how to control heat and noise radiation carried out at one of the Ship Production Companies in Indonesia, using the checklist sheet. Data that have been obtained from observations were analyzed descriptively and the data were categorized inti 2 categories, which are good if all actions in the control are carried out and not good if only a few actions in the control are carried out, then they were written in narrative form to draw conclusions.

\section{RESULT}

\section{Noise}

Based on secondary data obtained from the Ship Production Company in Indonesia, it was described that about $59.1 \%$ of workers were exposed to noise that did not meet the requirements or exceeds the threshold standard and only about $40.9 \%$ of workers exposed to noise which were still eligible or still within appropriate standard threshold value.

\section{Radiation Heat}

Based on the secondary data obtained from Ship Production Companies in Indonesia, it was illustrated that around $59.1 \%$ of workers exposed to heat radiation were still eligible or still in accordance with the threshold value and about $40.9 \%$ of workers exposed to heat radiation who were not eligible or not according to the standard threshold value. It means that the heat pressure in the working environment of the Ship Production Company in Indonesia was still quite safe for the workers.

\section{Technical Control}

Based on the secondary data from Ship Production Company in Indonesia, it was found that the engineering controls carried out were inadequate. It is because the Ship Production Company in Indonesia did not carry out all the efforts that should be done, in which only a few attempts were made, including the absence of control techniques by means of isolating heat sources, did not close or insulate the engine or work equipment that emits noise, but carried out regular engine maintenance, and reduced noise on the transmission media.

\section{Administrative Control}

Based on the secondary data from Ship Production Company in Indonesia, it was found 
that the administrative controls that had been carried out were sufficient. Administrative controls carried out included the provision of supplementary food for workers, periodic health checks at least once a year, signs in the form of warning boards installed in hazardous areas such as areas with high noise intensity, the implementation of job rotation (movement of workers from one job to other work in one work unit at a job), the availability of adequate bathrooms/toilet, and information about K3/safety talk.

\section{The Control of Personal Protective Equipment (PPE)}

Based on the secondary data from Ship Production Company in Indonesia, it was found that the supply of Personal Protective Equipment (PPE) had met the requirements, because the quantity and quality were sufficient. The Personal Protective Equipment (PPE) owned was complete. PPE that was owned includes ear muffs, ear plugs, helmets, safety shoes, sunglasses, tan gloves, and wearpacks. The inspection and maintenance of all PPE were carried out by the K3 department. In addition, there was training on the use of PPE for workers.

\section{DISCUSSION}

\section{Noise}

The results shown in noise indicate that more workers exposed to noise which did not meet the requirements or exceeded the threshold value. Noise from sound sources will produce various effects, so there is a need for noise control such as periodic noise monitoring and auditory testing using audiometry tests. Other controls that can be done are by installing barriers, dampers and the use of personal protective equipment. Meanwhile, the effort of personal prevention is by using earplugs or earmuffs (Dewanty and Sudarmaji, 2015).

Noise experienced by workers is continuous noise means noise that comes continuously for a long time. This relates to the conditions in the work environment of one of the Ship Production Companies in Indonesia, such as noise from the grinding used to cut material that was carried out continuously, welding activities, repair activities, and noise from blowers causing constant noise intensity and occurred in a long time. Noise that occurs continuously can be dangerous for workers.
The impacts that can occur were directly to the ear (auditory effect) and indirectly to the ear (nonauditory effect) (Andriani, 2017).

One of the regulations governing the noise threshold is the Regulation of the Minister of Health of the Republic of Indonesia Number 70 of 2016 concerning Health Standards and Requirements of the Industrial Work Environment. The regulation states that the noise quality standard for 8 working hours per day is $85 \mathrm{~dB}$ and this regulation does not apply to impulsive noise or booms lasting of $<3$ seconds (Ministry of Health Regulation, 2016). Similarly, the Regulation of the Minister of Manpower and Transmigration of the Republic of Indonesia Number Per/1/MEN/X/2011 concerning Threshold Value of Physical and Chemical Factors in the Workplace states that within exposure time of 8 hours per day, the allowable noise is $\leq 85 \mathrm{~dB}$ (A) (Ministry of Manpower and Transmigration, 2011).

\section{Radiation Heat}

According to the results that have been obtained at one of the Ship Production Companies in Indonesia, more workers are exposed to heat which were eligible or still according to the threshold value. Workload data were obtained from secondary data, stating that one of the Ship Production Companies in Indonesia showed that the workload was classified as moderate. This was adjusted to the Regulation of the Minister of Manpower and Transmigration of the Republic of Indonesia Number Per/13/MEN/ X/2011 concerning Threshold Value of Physical and Chemical Factors in the Workplace which states that the working time setting is $75 \%-100 \%$ with $25 \%$ of time break from 8 working hours (Ministry of Manpower and Transmigration, 2011).

However, a control must be done so that the workforce can work productively and avoid occupational diseases or accidents due to work. If labor exposed to heat exceeding the allowed threshold standard, it can cause occupational diseases and work accidents that result in decreased work productivity. So that the work environment with high temperatures is something that needs to get more supervision, because it causes more problems than the work environment with low temperatures (Wulandari and Ernawati, 2018).

Heat control at the heat source can be considered as the first solution to reduce radiant heat by installing reflective aluminum barriers in the industry. This can reduce ISBB by $3.9 \mathrm{oC}$. Besides, it can also be done by providing a fan so that air 
circulation can run well and reduce the heat received by workers and restore body temperature to normal (Lestari, Raharjo and Yunita, 2018).

\section{Technical Control}

A good work environment will produce a good work system which makes a worker feel at home with his workplace and does not cause physiological disturbance to humans as well as to the time of work completion. Based on secondary data obtained, control was not carried out through heat source isolation. Isolation control technique is a control technique by moving workers to an area with a lower heat radiation level or increasing the distance of the heat source so that the heat pressure level reaching the body can be reduced. However, this cannot be done by the company because it is impossible and the monitoring cannot be done remotely.

The closure or insulation carried out by one of the Ship Production Companies in Indonesia on machines that produce noise sources also still cannot run effectively, because the noise level of the tool used still exceeds the noise threshold value. It is better to reduce the noise by insulating the source of noise so that workers can be more productive when working. The importance of insulation is because the sound insulation/silencer becomes an effective means to reduce air-borne noise (Setyawan, Zakki and Iqbal, 2015). So, the company must prioritize the elimination of noise hazards in noise control.

One of the engineering control efforts that has been carried out by one of the Ship Production Companies in Indonesia was periodic engine maintenance. This activity was carried out once a month. Engine maintenance is very important. This is done in order to keep the machine always in a state ready for use optimally and not cause danger to labor, so that the production process can run smoothly. The party responsible for periodic engine maintenance is K3. Maintenance carried out included preventive maintenance such as inspecting, lubricating and checking machines as thoroughly as possible. This preventive maintenance has various objectives, those are achieving the optimal level of industry readiness by preventing damage and reducing the period of repair to a minimum possible, maintaining the best possible condition of the machine, and ensuring the level of safety of workers.

The company has also made other efforts to reduce noise by using transmission media. This media is in the form of planting trees around the company's work environment. The use of this transmission media is expected to reduce or decrease the noise or acts as a noise barrier. Research on blocking vegetation noise has been carried out by Pudjowati on Waru-Sidoarjo toll road, East Java, Indonesia. The results showed that the noise barrier with vegetation composition consisting of trees, shrubs and bushes was more effective in reducing noise (up to $12.25 \%$ ) and lowering the temperatures (up to 8.81\%) (Pudjowati et al., 2013). It means that the use of plants as barrier or reducing noise is very effective.

In preventing work accidents due to exposure to heat and noise radiation in the work environment of Ship Production Company in Indonesia, it has inadequate technical control because not all engineering controls were carried out.

\section{Administrative Control}

A hot and noisy work environment requires workers who are fit, have good physical fitness, good health status, good nutritional status, and good mental health. Based on the secondary data obtained, workers have their health status checked once a year, provided by additional food and also worked in rotation. This was done by the company so that workers can work in accordance with their duty. In line with Sutrisna's research, the advantage of doing job rotation is that it can reduce the level of burnout and increase morale with various activities carried out, and also can provide indirect benefits for the company, because employees who have more skills will be able to manage their work and can easily adapt to changes in the work environment. (Sutrisna, Zenju and Pratidina, 2018).

The provision of bathrooms by the Ship Production Company in Indonesia for workers is considered as sufficient. In accordance with the Regulation of the Minister of Health of the Republic of Indonesia No. 70 of 2016 concerning Standards and Requirements for Industrial Environmental Health, it is stated that the standard quality of toilet facilities for industry workers with 111-150 workers must be available as many as 6 toilets, and plus 1 toilet for each additional 40 person (Ministry of Health Regulation, 2016).

The provision of danger signals in an effort to control noise and heat radiation in one of the Ship Production Companies in Indonesia has been carried out in general. Placing warning signs in hazardous areas such as areas with high noise intensity is needed. This is in accordance with Saputra's opinion, 
that the hazard sign must contain the source of the hazard contained in the location, the effect caused by the source of the hazard, and how to overcome it by using PPE according to the source of the hazard (Saputra, 2017).

Safety Talk has been carried out by one of the Ship Production Companies in Indonesia to increase workers' awareness of occupational safety and health procedures. This safety talk was conducted regularly in the morning and delivered by HSE. Safety talk that is held before work is very effective in meeting the needs of employees in information about K3 and can build awareness of workers to prioritize safety in order to avoid work accidents (Kurniawan, Setyaningsih and Wahyuni, 2017).

All administrative control efforts that have been made by one of the Ship Production Companies in Indonesia are inseparable from various supports, including skilled, professional, and qualified human resources so that they can identify factors of work accidents that occur due to noise sources and heat sources, so that they can control these factors with administrative efforts that have been implemented.

Another reason that supports administrative efforts in controlling noise and heat radiation is the budget of funds owned by one of the Ship Production Companies in Indonesia which is sufficient, so that it can procure the materials needed in the administrative effort to control noise and radiation pans. Another carrying capacity is the management that has been carried out at the Ship Production Company in Indonesia, so that administrative efforts to control noise and heat sources can be carried out.

\section{The Control of Personal Protective Equipment (PPE)}

The use of personal protective equipment in the hazard control hierarchy is the ultimate hazard control method. In implementing the work safety system, the Ship Production Company in Indonesia has implemented the obligation to use PPE for work health and safety for every worker in the workplace that has potential and hazard factors, especially in areas of noise and heat sources. Previously, the company has also conducted a noise analysis, where the noise analysis is useful to find out the location where workers are required to use hearing protective equipment. Some areas in one of the Ship Production Companies in Indonesia have high noise levels or are within the insecure noise threshold according to the Regulation of the Minister of Manpower and Transmigration of the Republic of Indonesia Number Per/13/MEN/X/2011 concerning Threshold Value of Physical Factors and Chemistry in the Workplace that is $85 \mathrm{~dB}(\mathrm{~A})$ for 8 working hours per day (Ministerial Regulation of Manpower and Transmigration, 2011), so in order to work in some areas that have a high noise level, workers are advised to wear hearing protective devices such as earplugs and earmuffs to prevent Occupational Disease due to continuous noise exposure.

PPE which is owned by one of the Ship Production Companies in Indonesia has been wellmanaged as an effort so that the danger can be eliminated or at least reduced. This is in accordance with Law No. 1 of 1970 , article 12 sub b on the law and regulations governing the obligations and rights of workers to use the required personal protection equipment (Law, 1970). In the company regulations and supervision, the use of PPE for workers have also been carried out. It is expected that the applicable regulations can guide workers in carrying out their work. In practice, this regulation requires workers to fill out forms every time the worker carries out a safety talk. Supervision is also an important factor in affecting a person's behavior. Changes in individual behavior starts from the stage of obeying without being willing to take an action and often only because they want to avoid being subject of punishment or sanctions. This supervision was carried out by the safety party or the K3 party, and the implementation has been optimal.

One of the Ship Production Companies in Indonesia also conducted training on the use of PPE for workers. This training course covered ways to use PPE correctly and the correct way to store PPE. This is intended to increase the insight and knowledge of workers through training that will raise awareness about the importance of using PPE, so that it is effective, used correctly, as well as maintained and stored appropriately. This is in accordance with Novianto's opinion stating that training can affect a person's behavior because training means changing behavior patterns ultimately through training (Novianto, 2015).

Publicly available PPE has been well fulfilled. The fulfillment of PPE in one of the Ship Production Companies in Indonesia is supported by various things, including the management system that is implemented well. This is also in accordance with the opinion raised by Alayyannur and Nilamsari that the storage of PPE must be arranged in such a way so that it is easily obtained and reachable by workers 
and the storage of PPE must be in a special place (Alayyannur and Nilamsari, 2016).

\section{CONCLUSION}

In an effort to control heat and noise radiation, one of the Ship Production Companies in Indonesia has implemented three control efforts from five control hierarchies, those are engineering, administrative control and PPE control. Among the three efforts that have been made, the technical control effort is still not good because in its implementation there are only a few actions taken in controlling the technique. Meanwhile, the administrative control and control of the use of PPE have been good because all of the performance control measures have been done.

\section{ACKNOWLEDGEMENT}

I would like to express my gratitude to all people/parties who have been involved in writing this scientific research either directly or indirectly, so that the writing of this research can be completed properly.

\section{REFERENCES}

Siswati, S., and Adriyani, R. (2017) 'Hubungan Pajanan Kebisingan dengan Tekanan Darah dan Denyut Nadi pada Pekerja Industri Kemasan Semen', Jurnal Kesehatan Lingkungan Indonesia, $16(1)$, pp. 29-36.

Alayyannur, P.A. and Nilamsari, N. (2016) 'Gambaran Manajemen Alat Pelindung Diri (APD) Di PT X Sidoarjo', Journal of Industrial Hygiene and Occupational Health, 1(1), pp. 80-100.

Amalia, R. D., Jayanti, S. and Kurniawan, B. (2015) 'Analisis Pengendalian Kebisingan Di Area Body Minibus Perusahaan Karoseri Tahun 2015', Jurnal Kesehatan Masyarakat (e-Journal), 3(3), pp. 616-626.

Andriani, K. W. (2017) 'Hubungan Umur, Kebisingan Dan Temperatur Udara Dengan Kelelahan Subjektif Individu Di Pt X Jakarta', The Indonesian Journal of Occupational Safety and Health, 5(2), pp. 112-120.

Aryantiningsih, D. S. and Husmaryuli, D. (2016) 'Kejadian Kecelakaan Kerja Pekerja Aspal Mixing Plant (Amp) \& Batching Plant Di Pt. Lwp Pekanbaru Tahun 2015', Jurnal Kesehatan Masyarakat Andalas, 10(2) pp. 145-150.
Dewanty, R. A. and Sudarmaji, S. (2015) 'Impact Analysis of Noise Intensity with Hearing Loss on Laundry Worker', Jurnal Kesehatan Lingkungan, 8 (2), pp. 229-237.

Fahri, S. dan E. P. (2010) 'Kebisingan Dan Tekanan Panas Dengan Perasaan Kelelahan Kerja Pada Tenaga Kerja Bagian Drilling Pertamina Ep Jambi', Prosiding Seminar Nasional Unimus, 26(4), pp. 307-320.

Failasufa, I., Pawenang, E. T. and Indarjo, S. (2014) 'Hubungan Kebisingan Dan Tekanan Panas Dengan Stres Kerja Pada Pekerja Bagian Spinning', Unnes Journal of Public Health, 3(1), pp. 1-10.

Fatimah, S. and Indrawati, F. (2018) 'Penyebab Kecelakaan Kerja PT. Pura Barutama Unit Offset', Higeia Journal of Public Health Research and Development, 1(3), pp. 84-94.

Kurniawan, W., Setyaningsih, Y. and Wahyuni, I. (2017) 'Hubungan Faktor Karakteristik Pekerja, Safety Morning Talk (Smt) Dan Housekeeping Dengan Kejadian Minor Injury Pada Pekerja Di Proyek Pembangunan Gedung Kantor Pt. X Jakarta', Jurnal Kesehatan Masyarakat Universitas Diponegoro, 5(3), pp. 323-331.

Law (1970) Number 1 Year 1970. Concerning Work Safety. Jakarta.

Lestari, D. T., Raharjo, M. and Yunita, N. A. (2018) 'Hubungan Paparan Panas Dengan Tekanan Darah Pada Pekerja Pabrik Baja Lembaran Panas', Jurnal Kesehatan Masyarakat (e-Journal), 6(6), pp. 79-86.

Ministryof Manpower and Transmigration (2011) Number 13 Year 2011. Concering Threshold Value of Physic Factor and Chemical Factors in the Workplace. Jakarta: Ministry of Manpower and Transmigration Republic Indonesia.

Ministry of Health Regulation (2016) Number 70 Year 2016. Concering Standards And Environmental Health Requirements Industrial Work. Jakarta: Ministry of Health of the Republic of Indonesia.

Notoatmodjo, S. (2012) Metodologi Penelitian Kesehatan. Jakarta: Rineka Cipta.

Novianto, N. (2015) 'Penggunaan Alat Pelindung Diri (APD) Pada Pekerja Pengecoran Logam Pt. Sinar Semesta (Studi Kasus Tentang Perilaku Penggunaan Alat Pelindung Diri (APD) Ditinjau Dari Pengetahuan Terhadap Potensi Bahaya Dan Resiko Kecelakaan Kerja Pada Pekerja Pengecoran L', Jurnal Kesehatan Masyarakat (e-Journal), 3(1), pp. 417-428. 
Pudjowati, U. R. et al. (2013) 'Effect of vegetation composition on noise and temperature in Waru - Sidoarjo highway, east Java, Indonesia', International Journal of Conservation Science, 4(4), pp. 459-466.

Rahadian, R. R. (2018) 'Hubungan tekanan Panas Dengan Denyut Nadi Pekerja Pada Area Kerja BRF Di PT X', Jurnal Ilmiah Kesehatan Media Husada, 6(2), pp. 285-294.

Rimantho, D. and Cahyadi, B. (2015) 'Analisis Kebisingan Terhadap Karyawan Di Lingkungan Kerja Pada Beberapa Jenis Perusahaan', Jurnal Teknologi, 7(1), pp. 21-27.

Saputra, F. E. (2017) 'Analisis Kesesuaian Penerapan Safety Sign Di PT Terminal Petikemas Surabaya’, The Indonesian Journal of Occupational Safety and Health, 5(2), pp. 121-131.
Setyawan, O., Zakki, A. F. and Iqbal, M. (2015) 'Analisa Estimasi Tingkat Kebisingan di Kamar Mesin dan Ruang Akomodasi pada Kapal Riset dengan Penggerak Motor Listrik Program Studi S1 Teknik Perkapalan, Fakultas Teknik, Universitas Diponegoro Semarang , Jurnal Teknik Perkapalan, 3(1), pp. 63-72.

Sutrisna, I., Zenju, N. S. and Pratidina, G. (2018) 'Pengruh Rotasi Kerja terhadap Kinerja Pegawai Struktural di RSUD Ciawi', GOVERNANSI, 4(April), pp. 11-20.

Wulandari, J. and Ernawati, M. (2018) 'Efek Iklim Kerja Panas Pada Respon Fisiologis Tenaga Kerja Di Ruang Terbatas', The Indonesian Journal of Occupational Safety and Health, 6(2), pp. 207215. 